\title{
THE SUGGESTION OF THE MACROPHOTO METHOD FOR THE EVALUATION OF THE GEAR DAMAGES BY PITTING
}

\section{Beáta KOPILÁKOVÁ1, Miroslav BOŠANSKÝ 2 , Ján ZÁPOTOČNÝ 3}

${ }^{1}$ Ing. Beáta KOPILÁKOVÁ, KTMaČS, FŠT, TnUAD in Trenčín, Pri parku 19, 91150 Trenčín Záblatie, SR, mail: beata.kopilakova@tnuni.sk,

2Prof. Ing. Miroslav BOŠANSKÝ, PhD., ÚDTaK, SjF STU Bratislava, Námestie slobody 17, 81231 Bratislava 1, SR, mail: miroslav.bosansky@stuba.sk,

${ }^{3}$ Ing. Ján ZÁPOTOČNÝ, KTMaČS, FŠT, KTMaČS, FŠT, TnUAD in Trenčín, Pri parku 19, 91150 Trenčín - Záblatie, SR, mail: jan.zapotocny@tnuni.sk.

Key words : pitting, gearing, USB microscope-camera, digital photos, photo method, tooth face.

Abstract It is necessary to determine regularly the span of a damaged gear surface caused by pitting. It is an arduous task, because the size of the damage on the tooth flank depends on the number of cycles and the torque. Therefore it is needed to check continually the degree of the surface damage during the testing. When evaluating it is needed to take into account both the area of one tooth and all teeth. In the past various tedious methods with the arduous manual evaluating were used to evaluate pitting. The article deals with the analysis and evaluating of pitting by a new original macrophoto method via the electronic microscope with the computer processing. The main advantage of this method is its speed, exactness and universality.

\section{INTRODUCTION}

During the operation of a gear there is a constant contact of the surface parts of teeth flanks between the pinion and the wheel. The high pressures are created here and the surface of the material is deformed by the load causing the enlargement of the contact area. The temperature rises and there are high pressures both on and under the surface of teeth flanks. This way several types of teeth damages can occur. The damage defect is understood as removing of the material surface

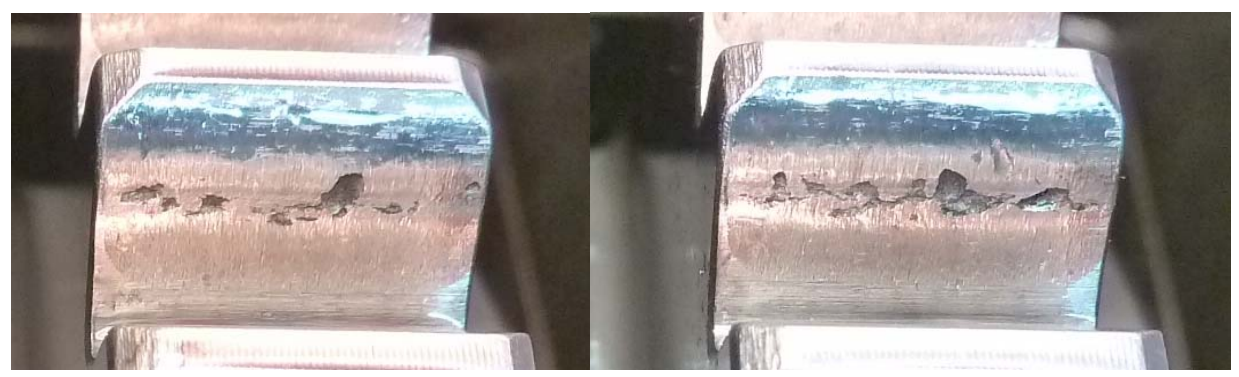

Figure 1: The samples of pitting after 18 million cycles under the load moment $265 \mathrm{Nm}$ and 725 turns per minute

during the stroke of two gear wheels. The important type of the contact damage defect of teeth 
flanks of the gears is pitting (fig.1). Although the pitting itself does not signify the danger of the gear damage from the functional point, there is a remarkable rise of noise, which causes that the gear becomes unworkable $[1,2,3]$.

Progressive (destructive) pitting occurs in the case of higher loads and it goes on creating pits of bigger dimensions and depth. There is a presumption that creation of pitting occurs mainly in the area under the rolling circle, or more precisely, on the root of teeth flanks.

\section{MATERIAL AND METHODOLOGY}

In general pitting is created as a damage defect of the tooth flank in any type of the gear (standardized and nonstandardized involute or noninvolute profiles). The place and time of pitting occurrence on the tooth flank (or number of cycles after which pitting occurs) depend highly on the size of the curvature radius, which differs in various types of gears providing that they have the same number of teeth and constant centre distances and this causes that pitting occurs under the same operation load and other operation conditions after different number of cycles (turns). Therefore it is necessary to measure the size of the damage defect of the tooth flank constantly, or

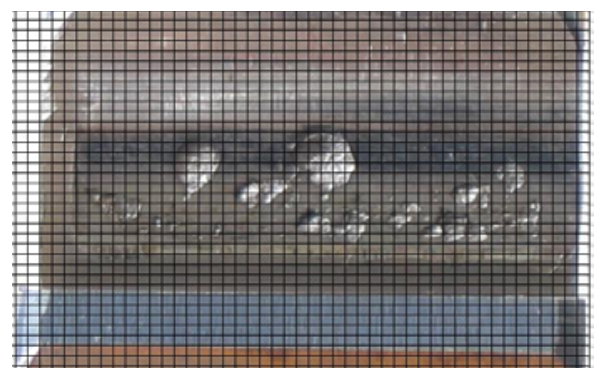

Figure 2: The photo covered by the graph paper

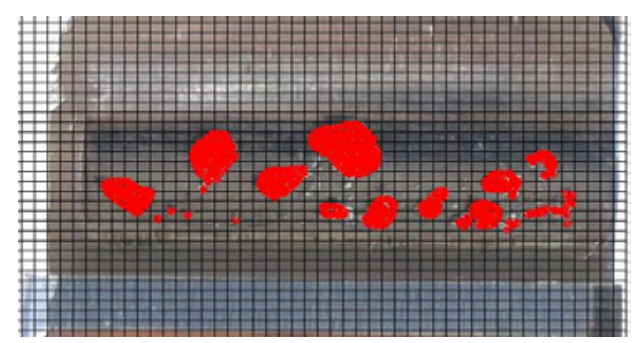

Figure 3: Manual marking of all areas damaged by pitting

better all teeth f flanks, because the terminal damage status is under $2 \%$ of total surface damage for all gear teeth or under $4 \%$ of the total surface damage for one tooth. Therefore the constant determining of the damaged area of the teeth flanks of the tested gear is regularly needed during the longevity testing. In the past there was the problem mainly with the elaborateness of the manual evaluating of received photos from the carried out testing. The damaged areas were read through the square net of the graph paper, which made the evaluation extremely laborious and slow, lacking the possibility of an automatic evaluating process (fig. 2,3). The situation was 
simplified by the use of digital cameras (fig. 4), or digital microscopes (fig. 5) and their connection with PC.

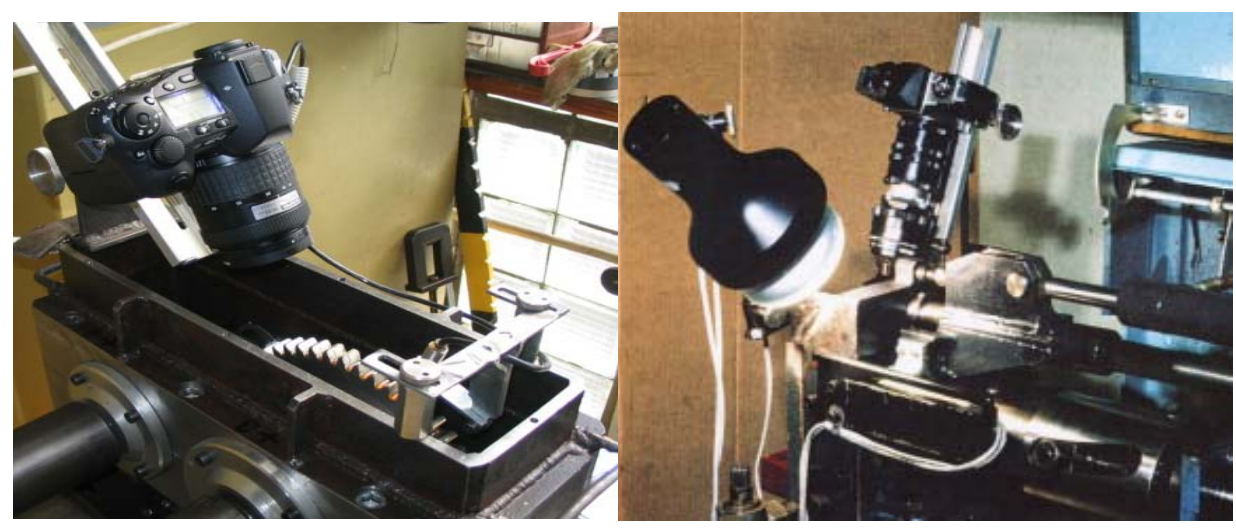

Figure 4: The method of pitting measuring via digital cameras

There are more methods for computer processing of degradation of the tooth flank surface by pitting, which use various software processing the digital photos of the gear teeth flanks and a mathematic-graphic program from the setting Matlab was developed for the automatic evaluation of the size of the damaged area. This program searches the surrounding of the pitting,

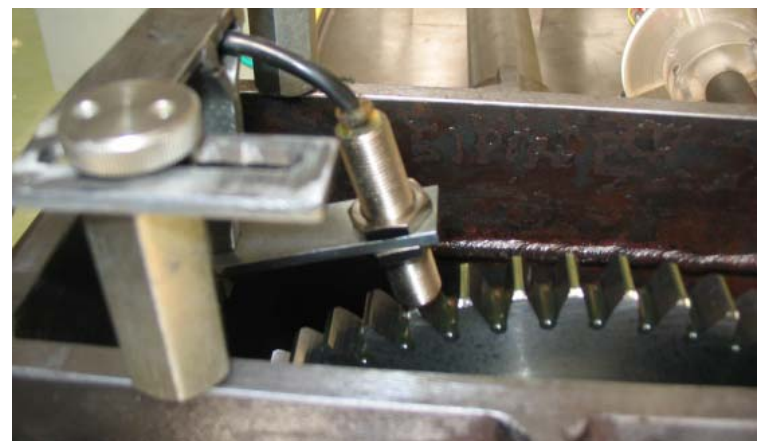

Figure 5: Detector of the gear turning

defines pixels with the high contrast and evaluates them as the terminal point of the damaged area $[4,5,6,7]$. The main watched output is the total size of the area damaged by pitting on one tooth and the whole gear, which is necessary for determining the terminal value of the pitting. The advantage of this method is that expensive and financially demanding equipment is not necessary, a digital camera is sufficient. Another advantage of this method is the speed of receiving the results and easier repeatability.

However, there is also a disadvantage. Indeed, the graphic program automatically selects the area and, based on the light and different colour, evaluates the area of pitting (pits of certain size and certain depth). The problem, however, is that the program does not recognize, mainly in 
the beginning phases of creating pitting, whether it is pitting or other damage, which is not pitting. Therefore the additional manual drawing of evaluated damages is needed.

The similar method of finding pitting damages is the method created at the Department of Machine Parts of the Faculty of Mechanical Engineering of Slovak University of Technology in Bratislava, where the digital camera was used to shoot the tooth flank damages [4,5]. The

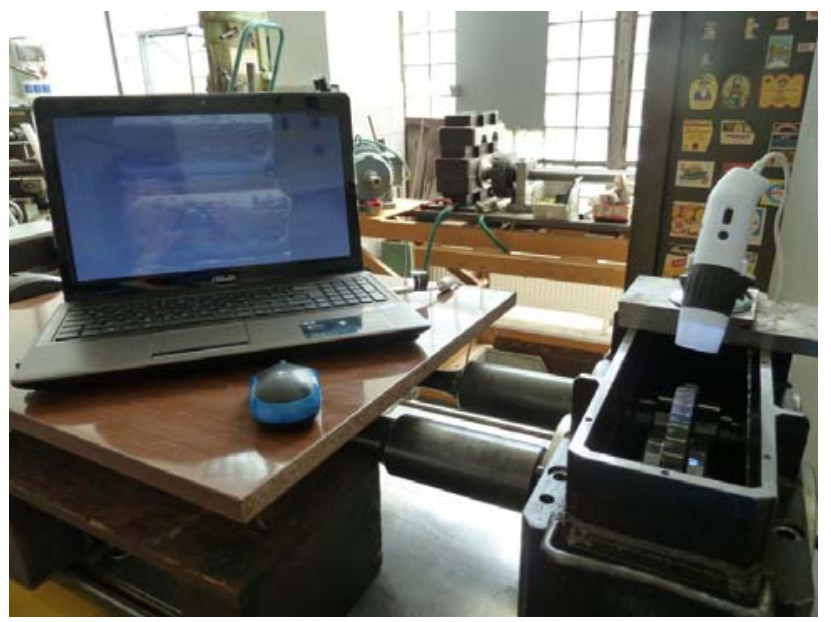

Figure 6: The testing equipment connected with $P C$

disadvantage of the method is the necessity of a long setting process and keeping stable light conditions while photographing to get the highest quality of the photos. For percentage evaluation of damages of individual teeth flanks by pitting the software Pitting-Check was created, which allows the digital photo processing. The program contains user tools which allow identifying in a simple way sampling the areas marked by pitting. At the same time the program takes into consideration geometric parameters of gearing such as bevelling, etc. The method makes the procedure of evaluation of the damaged status during the experiment more effective.

For the precise evaluation of pitting creation first it is necessary to set a precise and unified methodology of measuring, to minimize impreciseness caused by systematic and accidental mistakes during experiments. The basic principle of testing arises from the Standard for testing of gears DIN 51354. The principle lies in the gradual loading of gearing and the determination of number of cycles carried out until the damage point of the tested sample. After the certain number of cycles the experiment is discontinued to evaluate the area of damages by pitting. We have suggested a new original macro photo method of evaluating pitting at the Institute of transport technology and engineering design, Faculty of Mechanical Engineering of Slovak University of Technology in Bratislava during evaluation of pitting creation on the convex-concave gear set. We used the digital microscope connected through USB interface to the personal PC. In this way digital images of individual teeth flanks of the tested gear set were created. Moreover, via this method the photos are enlarged and at the same time recorded directly in the PC. (fig. 6). The above mentioned Pitting-Check software, which allows processing of digital images was used for the percentage evaluation of damages of individual teeth flanks by pitting. To detect and evaluate damages of teeth flanks from the point of view of pitting a digital USB- Microscope-Camera 1,3 
Mio. Pixel for scanning or photographing of each tooth flank of the gear (fig. 6) was used. By connecting the microscope online to the computer via USB interface it is possible to ensure the precise turning of the shaft of the electromotor at any moment to shoot the image needed for evaluation via connected microscope automatically. Via the controlling software of the microscope called "eScope" the period of shooting the photos by the microscope is defined, taking into consideration several requirements to shoot the tested tooth in the needed quality and necessary enlargement, i.e. the whole tooth with the sufficient brightness, which creates the optimum conditions for the computer processing of the received photo from the point of view of pitting formation. The whole process is automatized by turning the gear by one tooth via the detecting unit navigating the turning of the gear (fig. 5). The period of taking the photos is defined via the software. This period must correspond with the period of turning of the driving electromotor.

The microscope with the resolution 1.3 MegaPixel is fully suitable for the suggested method. On the market there are also microscopes with the resolution more than 2 MegaPixel available. Considering the evaluating software, the microscope with the resolution lower than 1.3 MegaPixel is sufficient. The reason is the compression of the output data. After multiplied compression of the processed data (to be concrete triple) the resolution of the final image is irreversible. Higher resolution of the image is not needed. It is limited by the possibilities of the program. The mistake span is $0,05 \%$, which is considerably higher preciseness compared to the methods used until now. The advantage of this method is that there are lightening diodes built inside the microscope, which illuminate the scanned surface, it means that measuring can be carried out also in a dark space, such as the inside of the gear without the necessity to disassemble the gear. Thus the problem of laborious and often complicated setting of the lightening of the scanned surface is removed.

The principle of the micrograph method is clear from the fig. 7 . The input is the photo received from the digital microscope. The program indicates the area which is analyzed, the

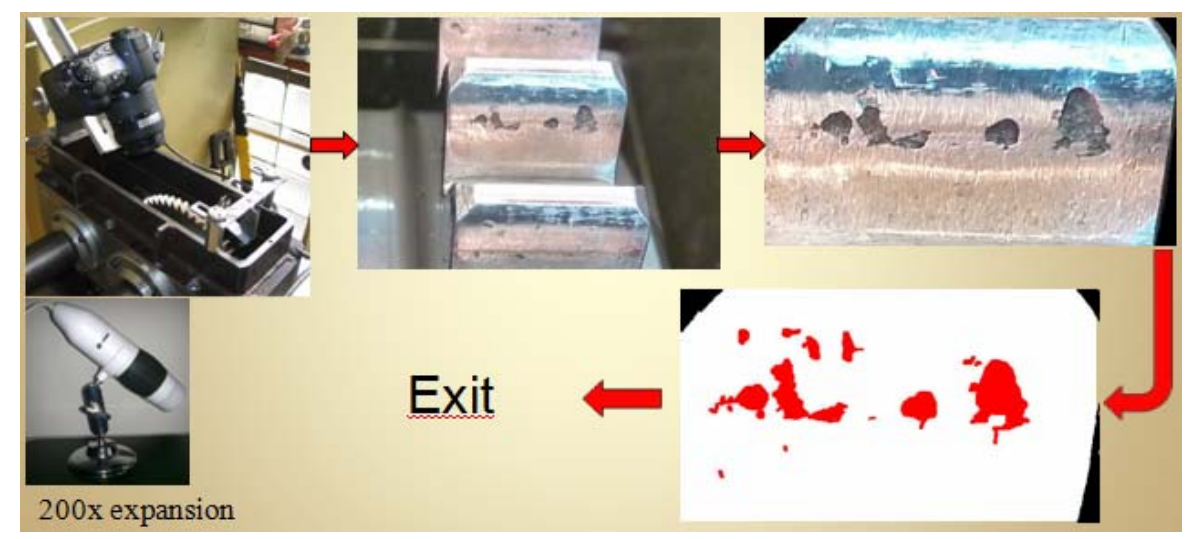

Figure 7: The principle of pitting evaluation via macrograph method

selection is made by the border line and after the process is finished the area outside the created shape is coloured in black (it can be a polygon). The program further deals only with the selected area and there are several additional options offered, such as brightness, contrast, saturation (only if it is needed and required in the selected area). The program itself recognizes the parts of the 
tooth face damaged by pitting and evaluates the area in the percentage. This process is automatically applied by the software on all photos made by the digital microscope. In this way all teeth flanks of the tested gear are evaluated and the process is repeated after each number of the pre-set cycles. The evaluation is finished only after all percentage results of the teeth flanks damages of all measurements are available.

The calculation of the percentage span of the teeth flanks damage by pitting determines the proportion of the marked area to the overall active area of the tooth, or the overall area of all teeth flanks. Based on the damage span the next procedure of the running experiment is started or it is finished. In the past other various slow methods were used to measure pitting. The main advantage of the presented method is its automatism and universality. It is sufficient just to set the frequency converter, scanning units and scanning apparatus properly.

\section{CONCLUSION}

It can be said that from the point of view of the speed and preciseness of the output processing the described original micrograph method ranks among the fastest and most precise methods. The principle of this method lies in using the complex features of the microscope used macro enlargement, lightening, recording and saving with the processing on the PC. So this method is simple, fast, effective, and mainly, universal. The method can be applied for measuring teeth faces damages by pitting with any type of the gear.

To conclude, it should be mentioned that the method of pitting measuring is the subject of the industrial patent approval. It is a new, original suggestion, which makes the pitting possibilities of continual evaluation of the pitting during the testing a lot easier. This method of evaluating is very fast compared to other methods, its great advantage is that any moment of the test is carried out in the digital surroundings, which secures the high quality of the results.

\section{REFERENCES}

The work was elaborated within the solution of grant projects VEGA 1/0277/12, 1/1035/12.

\section{REFERENCES}

[1] BOŠANSKÝ, M., KOŠA, R., VEREŠ, M., MEDZIHRADSKÝ, A., NEMČEKOVÁ, M.: Možnosti vyhodnotenia poškodenia boku zuba pittingom. In: Nové trendy v konštruovaní a v tvorbe technickej dokumentácie 2006. Nitra, Slovenská pol’nohospodárska univerzita, 2006, ISBN 978-80-552-0585-4, s.84-91.

[2] BOŠANSKÝ, M., VEREŠ, M., RUSNÁK, J., TÖKÖLY, P.: Konštruovanie II. STU Bratislava, 2009, 325 s., ISBN 978-80-227-3510-0.

[3] ČERNY, M., FILIPEK, J., MAZAL, P.: Pitting damage of gears. Acta univ. agric. et silvic. Mendel. Brun., 2010, LVIII, No. 2, pp. 51-60.

[4] KOPILÁKOVÁ, B.,BOŠANSKÝ, M.: Možnosti zvýšenia únosnosti ozubených prevodov z hl'adiska pittingu. In: Nové trendy v konštruovaní a v tvorbe technickej dokumentácie 2011: pri 
SCIENTIFIC PROCEEDINGS 2012, Faculty of Mechanical Engineering, STU in Bratislava Vol. 20, 2012, pp. 93-99, DOI: 10.2478/v10228-012-0015-6

príležitosti 42. výročia založenia Technickej fakulty SPU v Nitre a 8 . Medzinárodného strojárskeho vel’trhu v Nitre. Nitra, SPU, 2011, ISBN 978-80-552-0585-4, s.84-91. 